\title{
BENTUK SCAFFOLDING DALAM PEMBELAJARAN MATEMATIKA MENGGUNAKAN APLIKASI BERBASIS TEKS
}

\author{
Kawakibul Qamar; Selamet Riyadi \\ Program Studi Pendidikan Matematika Universitas Kanjuruhan Malang \\ ikings94@unikama.ac.id
}

\begin{abstract}
ABSTRAK. Mobile Learning dapat digunakan dalam meningkatkan kemampuan siswa dalam pembelajaran matematika. Pembelajaran matematika menggunakan aplikasi berbasis teks yaitu Short Message Service (SMS) merupakan salah satu bagian dari mobile learning. Aplikasi berbasis teks ini sangat populer di kalangan remaja usia sekolah. Pembelajaran matematika yang menggunakan aplikasi berbasis teks sangat cocok menggunakan strategi scaffolding. Teks dalam scaffolding dapat berupa questioning, prompting, cueing, serta direct explanation. Tujuan penelitian ini berupaya untuk mendeskripsikan bentuk scaffolding dalam pembelajaran matematika berdasarkan teks yang dihasilkan menggunakan aplikasi berbasis teks. Berdasarkan data yang dikumpulkan berupa data kualitatif, maka metode penelitian yang digunakan adalah kualitatif deskriptif. Dari hasil temuan subjek penelitian dapat melakukan proses pembelajaran matematika dan aktif dalam melakukan interaksi menggunakan aplikasi berbasis teks ini. Penggunaan scaffolding dengan bentuk questioning, prompting, cueing, explaining terlihat dalam transkripsi.
\end{abstract}

Kata Kunci: pembelajaran matematika, aplikasi berbasis teks, SMS, scaffolding

\section{PENDAHULUAN}

Mobile Learning dapat digunakan dalam meningkatkan kemampuan siswa dalam pembelajaran matematika. Baya'a (2009) menyatakan pemanfaatan pembelajaran matematika yang menggunakan mobile learning pada mahasiswa jurusan pendidikan mengakibatkan kombinasi yang baik dalam pembelajaran matematika di dalam kelas. Pembelajaran yang menggunakan aplikasi berbasis teks yaitu Short Message Service (SMS) merupakan salah satu bagian dari mobile learning. Aplikasi berbasis teks ini sangat populer di kalangan remaja usia sekolah. Menurut Wang (2009) mobile learning berbasis teks sangat berguna untuk mendukung kegiatan pembelajaran khususnya kegiatan di luar kelas. Kegiatan pembelajaran menggunakan SMS dapat diterapkan dalam pembelajaran remedial teaching Matematika di SMK (Qamar, 2013). Bahkan menurut Lomine (2009) menyatakan bahwa pembelajaran berbasis teks (Short Message Service/SMS) dapat meningkatkan motivasi dan retensi siswa. Pemanfaatan aplikasi berbasis teks melibatkan keaktifan siswa untuk menggali kemampuan siswa dalam memahami suatu konsep. Sehingga pembelajaran yang memanfaatkan aplikasi berbasis teks dapat diterapkan dalam proses pembelajaran matematika. Pembelajaran matematika yang menggunakan aplikasi berbasis teks sangat cocok menggunakan strategi scaffolding. Bentuk Scaffolding dapat dikonversi dalam bentuk berupa teks yang digunakan untuk mengarahkan siswa dalam proses pembelajaran. Teks dalam scaffolding dapat pertanyaan arahan sehingga dapat membantu siswa dalam meningkatkan pemahaman terhadap suatu konsep matematika. berupa questioning, prompting, cueing, serta direct explanation (Fisher, 2010).

Masalah penelitian ini memfokuskan pada bagaimana bentuk scaffolding pada pembelajaran Matematika menggunakan aplikasi berbasis teks. Sehingga tujuan penelitian ini berupaya untuk mendeskripsikan bentuk scaffolding dalam pembelajaran matematika berdasarkan teks yang dihasilkan menggunakan aplikasi berbasis teks. 


\section{Scaffolding dalam Pembelajaran Matematika}

Pembelajaran Matematika merupakan proses transfer pengetahuan baik pemahaman konsep maupun keterampilan prosedural sehingga pembelajar memiliki pengetahuan yang lebih tinggi. Hal ini sejalan dengan tujuan dari pendidikan nasional yang mengharuskan pendidik untuk mengembangkan potensi peserta didik (siswa) agar menjadi manusia yang beriman dan bertakwa kepada Tuhan Yang Maha Esa, berakhlak mulia, sehat, berilmu, cakap, kreatif, mandiri, dan menjadi warga negara yang demokratis serta bertanggung jawab. Tujuan tersebut terangkum dalam sistem pendidikan nasional sebagaimana tercantum dalam Undang-Undang Nomor 20 Tahun 2003 tentang Sistem Pendidikan Nasional. Untuk meraih tujuan sistem pendidikan nasional khususnya siswa yang kreatif, dapat menggunakan strategi Scaffolding. Scaffolding dalam konteks pendidikan adalah proses pemberian kerangka belajar dari pendidik kepada mahasiswa. Hal ini sesuai dengan Lawson (2002) yang menyatakan bahwa "Scaffolding in an educational context is a process by which a teacher provides students with a temporary framework for learning". Pemberian Scaffolding akan mendorong peserta didik mengembangkan inisiatif, motivasi, dan sumber daya mereka sehingga diharapkan tumbuh kompetensi kreativitasnya.

Konsep Scaffolding digunakan untuk memberikan pemahaman interaksi antara orang dewasa dan anak (Stone, 1998). Scaffolding dalam pembelajaran merupakan strategi mengajar yang terdiri dari mengajar suatu keterampilan baru dengan mengajak peserta didik bersama-sama menyelesaikan tugas yang dirasa terlalu sukar apabila siswa menyelesaikannya sendiri kemudian pendidik memberikan bantuan belajar secara penuh dan kontinyu, dalam hal ini scaffolding untuk membantu siswa membangun pemahaman atas pengetahuan dan proses yang baru.

Pendidik juga dapat menggunakan pertanyaan sebagai scaffolding untuk membantu siswa untuk memecahkan masalah atau menyelesaikan tugas. Pendidik mungkin meningkatkan tingkat pertanyaan atau kekhususan sampai siswa tersebut mampu memberikan respon yang benar (Stuyf, 2002: 4). Pertanyaan tersebut dapat berupa kata-kata yang dituliskan sehingga dalam aplikasi berbasis teks, suatu scaffolding dapat dilakukan. Menurut Fisher (2010), bentuk scaffolding yang dilakukan oleh pendidik dalam membantu siswa terdiri dari empat bagian, yaitu:

1. Questioning untuk memeriksa pemahaman,

2. Prompting untuk memfasilitasi proses kognisi siswa,

3. Cueing untuk mengalihkan perhatian siswa menjadi fokus pada informasi yang lebih khusus, kesalahan atau pemahaman parsial,

4. Explaining untuk siswa yang belum memiliki pengetahuan yang cukup untuk menyelesaikan tugas.

\section{METODE PENELITIAN}

Penelitian ini melibatkan siswa Sekolah Menengah Kejuruan (SMK) yang sedang mengatasi kesulitan dalam kompetensi Konsep Peluang. Pembelajaran matematika dilakukan menggunakan aplikasi berbasis teks yang dipandu oleh peneliti sebagai instrumen penelitian utama yang merencanakan, melaksanakan, mengolah data (mengambil, menganalisis, mendeskripsikan, menyimpulkan) serta melaporkan hasil penelitian. Kegiatan penelitian ini berkenaan dengan penyimpanan catatan (hasil rekaman aplikasi berbasis teks) dan pengumpulan pengalaman dalam pembelajaran. Penelitian ini menggunakan data kualitatif berdasarkan analisis pada rekaman data teks yang digunakan selama pembelajaran. matematika menggunakan aplikasi teks.

\section{HASIL DAN PEMBAHASAN}

Proses pembelajaran matematika menggunakan aplikasi berbasis teks ini terjadi dengan baik. Hal ini ditunjukkan dari rekaman data transkripsi antara subjek dengan peneliti. Adapun hasil 
penelitian berupa transkripsi dari beberapa poin yang dijelaskan berupa tabel, mulai tabel 1 sampai dengan tabel 4. Tabel tersebut ditunjukkan sebagai berikut.

Tabel 1. Bentuk Scaffolding Questioning

\begin{tabular}{ll}
\hline Peneliti & $\begin{array}{l}\text { Qudsy mempunyai 4 kaos dan 3 celana. Dengan berapa pasangan berbeda, dia dapat } \\
\text { memakai kaos dan celana tersebut? }\end{array}$ \\
\hline Subjek & 12 pak . \\
\hline Peneliti & darimana dapat 12 itu? \\
\hline Subjek & Kaos 4 x 3 clna $=12$ \\
\hline Peneliti & mengapa pakai perkalian? caranya untuk memastikan bagaimana? \\
\hline Subjek & Msal kaos 1 utk celna 1,2,3 \\
& Kaos 2 utk clna 1,2,3 \\
& Kaos 3 utk clna 1,2,3 \\
& Kaos 4 utk clna 1,2,3 \\
& Jd kaos bsa d.pke dgn clna 12x
\end{tabular}

Berdasarkan transkripsi pada tabel 1, subjek sebenarnya sudah bisa menjawab namun, untuk meyakinkan jawaban tersebut maka dapat digunakan scaffolding dengan bentuk questioning sehingga kelihatan bahwa subjek memang benar sepenuhnya memahami tentang jawaban soal tersebut.

Tabel 2. Bentuk Scaffolding Prompting

\begin{tabular}{|c|c|}
\hline Peneliti & $\begin{array}{l}\text { Peluang tembakan A mengenai sasaran adalah 0,25 dan peluang tembakan B meleset } \\
\text { dari sasaran adalah 0,4. Jika A dan B masing-masing menembak, hitung peluang } \\
\text { tembakan keduanya mengenai sasaran? }\end{array}$ \\
\hline Peneliti & bagaimana? bisa?? \\
\hline Subjek & $\begin{array}{l}P(a)=0,25 \\
\text { Krn mlset } P(b)=1-0,4=0,6 \\
P(a u b)=p(a)+p(b)=0,25+0,6=0,85 \text { pak hsilx }\end{array}$ \\
\hline Peneliti & karena kata hubung “dan” berarti pakai gabungan ataukah irisan?? \\
\hline Subjek & $\begin{array}{l}\text { Y ampun iya pak, dan brti irisan } \\
\mathrm{Jd} \text { p(a).p(b) }=0,15\end{array}$ \\
\hline
\end{tabular}

Berdasarkan transkripsi pada tabel 2, subjek dirasa terlalu lama dalam mengajukan jawabannya sehingga diberi scaffolding bentuk questioning, namun respon dari subjek masih terdapat kesalahan sehingga diberikan scaffolding dengan bentuk prompting, dan hasilnya subjek menyadari letak kesalahannya.

Tabel 3. Bentuk Scaffolding Cueing

\begin{tabular}{ll}
\hline Peneliti & $\begin{array}{l}\text { Tiga kartu diambil dari seperangkat kartu bridge secara acak, berapa peluang } \\
\text { mendapatkan semuanya As? }\end{array}$ \\
\hline Subjek & Gni a pak ? \\
& $\begin{array}{l}\mathrm{n}(\mathrm{a})=4 \\
\mathrm{n}(\mathrm{s})=52 \mathrm{jd} 4 / 52=1 / 13\end{array}$ \\
\hline Peneliti & kan ada 3 as, berapa banyak komposisinya? \\
\hline Subjek & Apa gni \\
& $\mathrm{n}(\mathrm{a})=4 \mathrm{C} 3=4 ! / 1 ! 3 !=4$ \\
& $\mathrm{n}(\mathrm{s})=52 \mathrm{C} 3=52 ! / 49 ! 31=22100$ \\
$\mathrm{n}(\mathrm{a}) / \mathrm{n}(\mathrm{s})=4 / 22100=1 / 5525$
\end{tabular}

Berdasarkan transkripsi pada tabel 3, subjek sudah menggunakan argumen untuk menyelesaikan soal, namun masih ada keraguan yang ditunjukkan dengan "Gni a pak ?" sehingga perlu diberi scaffolding dengan bentuk cueing seperti yang ditunjukkan dalam tabel 2 tersebut. 
Tabel 4. Bentuk Scaffolding Explaining

\begin{tabular}{|c|c|}
\hline Peneliti & $\begin{array}{l}\text { soal terakhir.. Suatu dadu sisi } 6 \text { dilempar } 2 \text { kali dan mata dadu yang muncul } \\
\text { dijumlahkan maka peluang jumlah mata dadu lebih dari } 10 \text { atau prima adalah... }\end{array}$ \\
\hline Subjek & $\begin{array}{l}\mathrm{n}(\mathrm{s})=36 \\
\mathrm{n}>10(\mathrm{a})=3 \\
\mathrm{n} \text { prima }(\mathrm{b})=3 \\
\mathrm{P}(\text { aub })=3 / 36+3 / 36=6 / 36=1 / 6\end{array}$ \\
\hline Peneliti & jumlah prima lho jd tdk hanya 3.. cari lagi... \\
\hline Subjek & $\begin{array}{l}\mathrm{n}(\mathrm{s})=36 \\
\mathrm{n}>10(\mathrm{a})=3 \\
\mathrm{n} \text { prima }(\mathrm{b})=11 \\
\mathrm{P}(\text { aub })=3 / 36+11 / 36=14 / 36=7 / 18\end{array}$ \\
\hline Peneliti & yakin hanya $11 ? ? ?$ coba apa saja?? \\
\hline Subjek & $2,3,5,7,11,13,17,19,23,29,31$ \\
\hline Peneliti & masak jumlah mata dadu lemparan 1 dan 2 bisa sampai $31 ? ? ?$ \\
\hline Subjek & $\begin{array}{l}\text { Oh } 6 \text { ya pak } \\
\text { Brti } p(b)=6 \\
P(a u b)=p(a)+p(b)=3 / 36+6 / 36=9 / 36=1 / 4\end{array}$ \\
\hline Peneliti & $\begin{array}{l}\text { kan jumlah mata dadu yang mungkin muncul terbesar } 6+6=12 \ldots \text { jadi yg prima kan } \\
2,3,5,7,11 \\
2 \text { itu }(1,1) \\
3 \text { itu }(1,2),(2,1) \text { dst.. }\end{array}$ \\
\hline Subjek & Truz ruang sampelx 12 pa yg 36 pak? \\
\hline Peneliti & $\begin{array}{l}\text { ruang sampelnya kan tetap... } 36 \text { karena kejadian yg mungkin }(1,1),(1,2)(2,1) \text {, sampai } \\
(5,6),(6,5),(6,6) \text { jadi ada } 36 \text { bukan??? }\end{array}$ \\
\hline Subjek & $\mathrm{P}(\mathrm{aub})=\mathrm{p}(\mathrm{a})+\mathrm{p}(\mathrm{b})=3 / 36+5 / 36=8 / 36=2 / 9$ \\
\hline Peneliti & $\begin{array}{l}\text { jumlah yg prima } \\
(1,1),(1,2),(2,1),(1,4),(4,1),(2,3),(3,2),(1,6),(6,1),(2,5),(5,2),(3,4),(4,3),(3,6),(6,3),(4,5), \\
(5,4),(5,6),(6,5) \text { berarti ada } 14\end{array}$ \\
\hline Subjek & Kok 14 pak bkanya $19 ?$ \\
\hline Peneliti & oia bkn 14 tp 19. hehehe.. \\
\hline Subjek & $\begin{array}{l}\text { Berrti } p(a u b)=p(a)+p(b)=3 / 36+19 / 36=22 / 36=11 / 18 \\
\text { Gni a pak? }\end{array}$ \\
\hline
\end{tabular}

Berdasarkan transkripsi tabel 4, merupakan scaffolding yang terbanyak, karena sebelum memunculkan bentuk scaffolding explaining harus melewati bentuk scaffolding questioning, prompting dan cueing. Hal ini dapat terjadi dimungkinkan pemahaman subjek masih tidak jelas, sehingga ketika menggunakan scaffolding explaining akhirnya proses tersebut bisa dengan mudah diterima oleh subjek.

Scaffolding yang diberikan dalam bentuk teks digunakan dalam pembelajaran matematika menggunakan aplikasi teks. Bentuk scaffolding yang terjadi bervariasi mulai yang sering banyak digunakan yaitu bentuk questioning sampai yang jarang digunakan dalam bentuk explaining. Scaffolding yang sering digunakan berupa questioning dan prompting sedangkan untuk bentuk cueing dan explaining digunakan ketika kemampuan subjek berada diluar Zone Proximal Development (ZPD).

\section{PENUTUP}

Dari hasil temuan subjek penelitian dapat melakukan proses pembelajaran matematika dan aktif dalam melakukan interaksi menggunakan aplikasi berbasis teks ini. Penggunaan scaffolding dengan bentuk questioning, prompting, cueing, dan bentuk explaining. Bentuk scaffolding dalam pembelajaran matematika berbantuan teks seperti berikut.

1. Questioning: darimana dapat $12 \mathrm{itu}$ ?

mengapa pakai perkalian? caranya untuk memastikan bagaimana?

bagaimana? bisa?? 
2. Prompting: karena kata hubung "dan" berarti pakai gabungan ataukah irisan?? jumlah prima lho jd tdk hanya 3 .. cari lagi... yakin hanya 11 ??? coba apa saja??

3. Cueing: kan ada 3 as, berapa banyak komposisinya? masak jumlah mata dadu lemparan 1 dan 2 bisa sampai 31??? Kok 14 pak bkanya 19 ?

4. Explaining: kan jumlah mata dadu yang mungkin muncul terbesar $6+6=12 \ldots$ ruang sampelnya kan tetap... 36 karena kejadian yg mungkin $(1,1),(1,2)(2,1)$,

\section{DAFTAR RUJUKAN}

Baya'a, N. dan Daher,W. 2009. Students' Perceptions of Mathematics Learning Using Mobile Phones. IMCL International Conference on Mobile and Computer aided Learning, (online),( www.imcl-conference.org) diakses 20 April 2016

Fisher, Douglas, 2010. Guided Instruction: How To Develop Confident And Successful Learners. USD: ASCD

Lawson, L.2002. Scaffolding as a Teaching Strategy. (online) (http://condor.admin.ccny.cuny.edu/roup a son a son Paper.doc), diakses tanggal 29 April 2016.

Qamar, Kawakibul. 2013. Pemanfaatan Short Message Service (SMS) dalam Remedial Teaching dengan menggunakan Scaffolding pada Materi Peluang di SMK PGRI 3 Malang. Tesis. Tidak diterbitkan. Universitas Negeri Malang.

Stone, A. 2004. Mobile Scaffolding: An Experiment in Using SMS Text Messaging to Support First Year University Students. Proceedings of the IEEE International Conference on Advanced Learning Technologies.

(online),(http://citeseerx.ist.psu.edu/viewdoc/download?doi=10.1.1.474.6854\&rep=rep1\&ty pe=pdf) diakses pada tanggal 21 April 2016

Stuyf., V. 2002. Scaffolding as a Teaching Strategy. Adolescent Learning and Development Journal. Section 0500A-Fall 2002.

(online),(http://workplacesafety.pbworks.com/f/Scaffold+Learning.doc) diakses pada tanggal 25 April 2016

Wang, Lei. 2009. Effectiveness Of Text-Based Mobile Learning Applications: Case Study In Tertiary Education. (online),(http://mro.massey.ac.nz/handle/10179/1092) diakses tanggal 20 April 2016 